Article

\title{
Phase Relations in MAFSH System up to 21 GPa: Implications for Water Cycles in Martian Interior
}

\author{
Chaowen $\mathrm{Xu}{ }^{1, *(1)}$ and Toru Inoue ${ }^{1,2,3}$ \\ 1 Geodynamics Research Center, Ehime University, 2-5 Bunkyo-cho, Matsuyama 790-8577, Japan; \\ toinoue@hiroshima-u.ac.jp \\ 2 Department of Earth and Planetary Systems Science, Hiroshima University, 1-3-1 Kagamiyama, \\ Higashi-Hiroshima 739-8526, Japan \\ 3 Hiroshima Institute of Plate Convergence Region Research (HiPeR), Hiroshima University, \\ Higashi-Hiroshima, Hiroshima 739-8526, Japan \\ * Correspondence: dkchaowen@126.com; Tel.: +81-050-3699-0952
}

Received: 3 August 2019; Accepted: 14 September 2019; Published: 16 September 2019

check for updates

\begin{abstract}
To elucidate the water cycles in iron-rich Mars, we investigated the phase relation of a water-undersaturated ( 2 wt. $\%$ ) analog of Martian mantle in simplified $\mathrm{MgO}-\mathrm{Al}_{2} \mathrm{O}_{3}-\mathrm{FeO}_{-} \mathrm{SiO}_{2}-\mathrm{H}_{2} \mathrm{O}$ (MAFSH) system between 15 and $21 \mathrm{GPa}$ at $900-1500{ }^{\circ} \mathrm{C}$ using a multi-anvil apparatus. Results showed that phase E coexisting with wadsleyite or ringwoodite was at least stable at 15-16.5 GPa and below $1050{ }^{\circ} \mathrm{C}$. Phase D coexisted with ringwoodite at pressures higher than $16.5 \mathrm{GPa}$ and temperatures below $1100{ }^{\circ} \mathrm{C}$. The transition pressure of the loop at the wadsleyite-ringwoodite boundary shifted towards lower pressure in an iron-rich system compared with a hydrous pyrolite model of the Earth. Some evidence indicates that water once existed on the Martian surface on ancient Mars. The water present in the hydrous crust might have been brought into the deep interior by the convecting mantle. Therefore, water might have been transported to the deep Martian interior by hydrous minerals, such as phase E and phase D, in cold subduction plates. Moreover, it might have been stored in wadsleyite or ringwoodite after those hydrous materials decomposed when the plates equilibrated thermally with the surrounding Martian mantle.
\end{abstract}

Keywords: high pressure; high temperature; Martian interior; water storage; water transport

\section{Introduction}

Water is an important volatile material that affects the physical and chemical properties of planetary interiors, such as those of Earth and Mars. Water transportation and storage are crucially important components of the water cycle, strongly affecting geodynamic processes. On Earth, several studies have indicated that some hydrous minerals can hold and transport water to the deep Earth by cold subducting slabs [1-3]. The so-called dense hydrous magnesium silicates (DHMSs) in $\mathrm{MgO}-\mathrm{SiO}_{2}-\mathrm{H}_{2} \mathrm{O}$ (MSH) system, such as phase $\mathrm{A}\left(\mathrm{Mg}_{7} \mathrm{Si}_{2} \mathrm{O}_{14} \mathrm{H}_{6}\right)$, phase $\mathrm{E}\left(\mathrm{Mg}_{2.3} \mathrm{Si}_{1.25} \mathrm{O}_{6} \mathrm{H}_{2.4}\right)$, superhydrous phase $\mathrm{B}$ $\left(\mathrm{Mg}_{10} \mathrm{Si}_{3} \mathrm{O}_{18} \mathrm{H}_{4}\right)$, phase $\mathrm{D}\left(\mathrm{MgSi}_{2} \mathrm{O}_{6} \mathrm{H}_{2}\right)$, and phase $\mathrm{H}\left(\mathrm{MgSiO}_{4} \mathrm{H}_{2}\right)$, are considered to be important carriers of subducted water from mantle transition zone down to the middle part of the lower mantle [4-9]. By contrast, the major minerals—wadsleyite and ringwoodite-in the Earth's mantle transition zone (MTZ), might act as a large water reservoir because they might hold several oceans' masses of $\mathrm{H}_{2} \mathrm{O}[10]$.

The existence of water on Mars has long been controversial. Recent studies of topographic features, for example, the northern plains, sedimentary deposits, and valley networks [11-13] and the detection of subsurface ice, as well as various hydrous minerals in Lyot crater, suggest the existence of an ancient Martian ocean on the surface [14-16]. The convecting Martian mantle may be hydrated 
when reacting with overlying hydrous crust, bringing water into the deep interior [17]. Therefore, similarly to an Earth-like planet, some hydrous minerals might exist in cold region of iron-rich Mars, and wadsleyite and ringwoodite might also hold a huge amount of water in the Martian interior, as it was argued for the present-day Earth.

Several studies have identified phase relations in the $\mathrm{MSH}$ and $\mathrm{MgO}-\mathrm{Al}_{2} \mathrm{O}_{3}-\mathrm{SiO}_{2}-\mathrm{H}_{2} \mathrm{O}$ (MASH) systems, with the observation of various hydrous minerals at $P-T$ conditions related to the cold subduction slabs $[3,4,6,7,18,19]$. Nevertheless, few data are available for hydrous iron-bearing systems: data for iron-rich systems, such as Mars, are rarely reported [5]. A better understanding of the phase relations in $\mathrm{MgO}-\mathrm{Al}_{2} \mathrm{O}_{3}-\mathrm{FeO}-\mathrm{SiO}_{2}-\mathrm{H}_{2} \mathrm{O}$ (MAFSH) system might help to elucidate the geodynamic processes associated with the deepwater cycles of Mars. Therefore, we determined the phase relations in iron-rich MAFSH system between $15 \mathrm{GPa}$ and $21 \mathrm{GPa}$ to systematically ascertain the stability of DHMSs, and further estimate the possible water transportation into the Martian interior by subducting processes.

\section{Materials and Methods}

High-pressure and high-temperature experiments were conducted at Geodynamics Research Center (GRC), Ehime University, using a Kawai-type 1000 ton multi-anvil apparatus. Tungsten carbide cubes with truncation edge length (TEL) of $4 \mathrm{~mm}$ were used in combination with Co-doped MgO-octahedra of $10 \mathrm{~mm}$ edge length (10/4 assemblage). Preformed pyrophyllite gaskets were used between the cubes, and $\mathrm{LaCrO}_{3}$ was used as the heater. A gold sample capsule was used in the cell assemblage. Pressures were calibrated at room temperature $\left(25^{\circ} \mathrm{C}\right)$ by diagnostic changes in the electrical resistances of ZnTe $(9.6$ and $12 \mathrm{GPa}), \mathrm{ZnS}$ (15.5 GPa), GaAs (18.3 GPa), and GaP (23 GPa) induced by the semiconductor-metal phase transitions at high pressures. The temperature was monitored using a $W_{97} R_{3}-W_{75} R_{25}$ thermocouple. The electromotive force (EMF) was not corrected for the effects of pressure. The sample was compressed to the desired pressure. Then, the oil pressure was held constant. Subsequently, alternating current (AC) power was supplied to the heater in the furnace assemblage. After heating for 40-240 $\mathrm{min}$, the power was stopped by shutting off the electric power supply. Samples were recovered after releasing pressure slowly during $12 \mathrm{hrs}$. The recovered run products were mounted in epoxy resin and were polished for phase identification and chemical composition analysis.

The simplified Martian composition by Dreibus and Wänke [20], which is an analog of the primitive Martian mantle composition corresponding to mantle + crust, was adopted. The oxide mixture of $\mathrm{MgO}$, $\mathrm{Al}_{2} \mathrm{O}_{3}, \mathrm{SiO}_{2}$, and $\mathrm{FeO}$ was prepared in appropriate proportions. $\mathrm{FeO}$ was put in the reduced furnace at $1000{ }^{\circ} \mathrm{C}$ for $24 \mathrm{~h}$ before mixing to ensure that the ferrous ion was used. We added $2 \mathrm{wt} . \% \mathrm{H}_{2} \mathrm{O}$ in the form of $\mathrm{Mg}(\mathrm{OH})_{2}$. The chemical compositions are presented in Table 1. To create a reduced environment, we inserted some Mo foil in a gold capsule before the starting material was encapsulated into the capsule. The phase assemblages were identified using a micro-focus X-ray diffractometer (MicroMax-007HF; Rigaku Corp., Tokyo, Japan) with $\mathrm{Cu} \mathrm{K} \alpha$ radiation. The obtained data were processed using 2PD software, which can display and process two-dimensional data, including smoothing, background correction, and 2D to 1D conversion. The micro-textures and composition were obtained using a field emission scanning electron microscope (FESEM, JSM7000F, JEOL, Akishima-shi, Japan) combined with an energy-dispersive X-ray spectrometer (EDS, X-MaxN, Oxford Instruments, Plc., Abingdon, UK). The $\mathrm{Fe}_{2} \mathrm{SiO}_{4}, \mathrm{Mg}_{2} \mathrm{SiO}_{4}$, and $\mathrm{Al}_{2} \mathrm{O}_{3}$ were used as standards in the EDS analyses. Working parameters of $15 \mathrm{kV}, 1 \mathrm{nA}$, and collection times of 30-50 s were used. The chemical composition was analyzed using EDS. We used software (Aztec ver. 2.4, Oxford Instruments Nanotechnology Tools Ltd., Abingdon, UK) to process EDS data. The Raman spectrum was obtained using laser Raman spectrometer (NRS-5100gr) to identify some of the recovered phases, with $532 \mathrm{~nm}$ laser excitation. Laser power applied to the sample was $10 \mathrm{~mW}$. The Raman spectra were obtained from a linear baseline, and peak characteristics were carried out using the commercial software package. The EDS measurements suggested that we obtained the homogeneous composition of Mo where it appeared. On the other hand, we calculated the chemical formula of garnet obtained in this study. The result showed that only the $\mathrm{Fe}^{2+}$ in the formula 
could make the charge balance. Therefore, we created a reduced environment in the sample chamber by using Mo foil.

Table 1. Chemical composition (wt.\%) of starting materials.

\begin{tabular}{ccccccc}
\hline Composition & $\mathbf{M g O}$ & $\mathrm{Al}_{2} \mathbf{O}_{3}$ & $\mathbf{F e O}$ & $\mathbf{S i O}_{2}$ & $\mathbf{H}_{\mathbf{2}} \mathbf{O}$ & Total \\
\hline $\mathrm{MAFSH}$ & 30.2 & 3.5 & 19.9 & 44.4 & 2 & 100 \\
\hline \multicolumn{7}{c}{ MAFSH, in simplified $\mathrm{MgO}-\mathrm{Al}_{2} \mathrm{O}_{3}-\mathrm{FeO}-\mathrm{SiO}_{2}-\mathrm{H}_{2} \mathrm{O}$ composition. }
\end{tabular}

\section{Results and Discussion}

\subsection{Phase Relations}

Experimental conditions and the results are presented in Table 2 and Figure 1 . Nominally anhydrous phases, such as clinopyroxene (Cpx), garnet (Gt), wadsleyite (Wd), and ringwoodite (Rw), were presented in quenched samples (Figure 2). Based on experimental conditions, different hydrous phases were observed with increased pressure. Phase $\mathrm{E}(\mathrm{PhE})$ was observed in the low-temperature region between 15-16.5 GPa to coexist with Gt and Wd or Rw, as presented in Figure 2a. It became unstable at 16.5 GPa with a temperature higher than $1100{ }^{\circ} \mathrm{C}$. However, the thermal stability limit of $\mathrm{PhE}$ in this study was about $100{ }^{\circ} \mathrm{C}$ higher than that reported in iron-free hydrous peridotite system [21]. Phase D (PhD) remained as a major hydrous phase at the present pressure range from $18 \mathrm{GPa}$ to $21 \mathrm{GPa}$ below $1100{ }^{\circ} \mathrm{C}$ (Figure 2b). With increased temperature, PhD decomposed to Rw, stishovite (St), and Gt. It seems that $\mathrm{PhD}$ in MAFSH system has the same stability region, as reported for a MASH system [21]. Therefore, it was expected that the $\mathrm{PhD}$ had a positive pressure-temperature stability slope, as presented in Figure 1. The high iron content in MAFSH system might inhibit the superhydrous phase B (SuB) formation, leading to the disappearance of $\mathrm{SuB}$ in the whole pressure range.

An earlier report described that the loop in the Wd-Rw boundary shifted towards higher pressure by the effect of water [22] or towards lower pressure with increased iron content [23]. In this study, $\mathrm{Wd}$ was stable up to $16 \mathrm{GPa}$ at $1200^{\circ} \mathrm{C}$; then it transformed to $\mathrm{Rw}$, as identified by Raman spectrum. The Rw formation was also found shifting to low pressure, which was observed at $16 \mathrm{GPa}$ and $1200{ }^{\circ} \mathrm{C}$. Therefore, this loop was influenced more strongly by the higher iron content than by the effects of $\mathrm{H}_{2} \mathrm{O}$ in the hydrous Martian mantle.

Table 2. Experimental conditions and results.

\begin{tabular}{cccc}
\hline Pressure (GPa) & Temperature $\left({ }^{\circ} \mathbf{C}\right)$ & Time (min) & Phase \\
\hline 15 & 900 & 240 & Gt, Wd, PhE \\
15 & 1100 & 240 & Gt, Wd, Cpx \\
15 & 1250 & 120 & Gt, Wd, Cpx \\
15 & 1450 & 90 & Gt, Wd, Cpx \\
16 & 1200 & 120 & Gt, Wd, Rw, Cpx \\
16.5 & 1100 & 120 & Gt, Rw, PhE, St \\
16.5 & 1300 & 90 & Gt, Rw, Cpx \\
18 & 1000 & 240 & Rw, PhD \\
18 & 1200 & 120 & Gt, Rw, St \\
18 & 1550 & 40 & Gt, Rw, St, Melt \\
19.5 & 1400 & 40 & Gt, Rw, St \\
21 & 900 & 240 & Rw, PhD, St \\
21 & 1050 & 240 & Rw, PhD, h-Fe \\
21 & 1250 & 120 & Gt, Rw, St \\
21 & 1500 & 40 & Gt, Rw, St \\
\hline
\end{tabular}

Gt, garnet; Cpx, clinopyroxene; Wd, wadsleyite; Rw, ringwoodite; St, stishovite; PhE, phase E; PhD, phase D; h-Fe, iron-rich hydrous phase. 


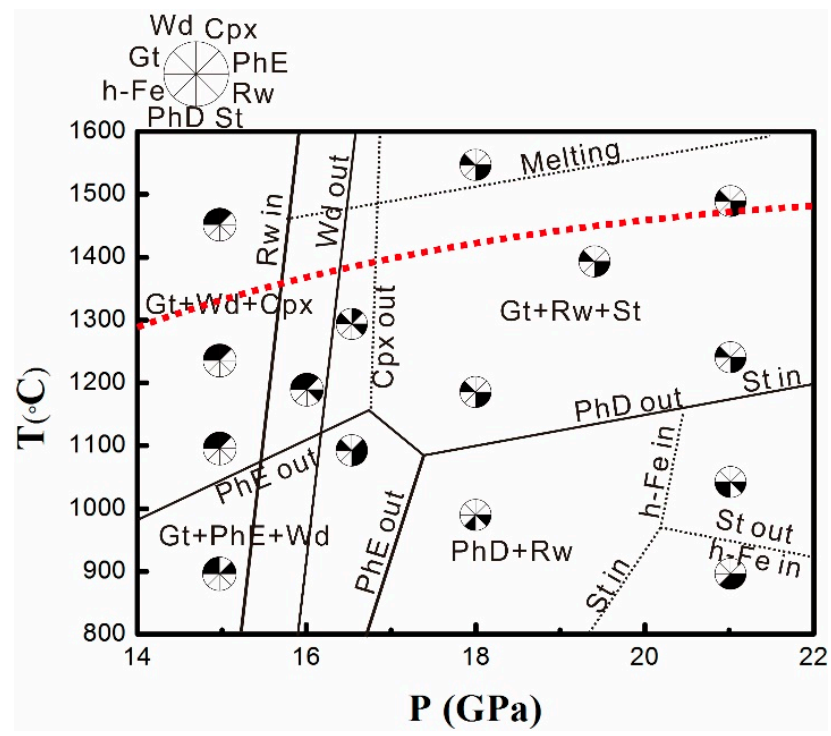

Figure 1. Phase relations in the system $\mathrm{MgO}-\mathrm{Al}_{2} \mathrm{O}_{3}-\mathrm{FeO}-\mathrm{SiO}_{2}$ with $2 \% \mathrm{H}_{2} \mathrm{O}$. Solidus lines are obtained according to the quenched samples combined with reported phase relation in $\mathrm{CaO}-\mathrm{MgO}-\mathrm{Al}_{2} \mathrm{O}_{3}-\mathrm{SiO}_{2}-$ pyrolite with $2 \% \mathrm{H}_{2} \mathrm{O}$ [24]. Dashed black lines are the proposed phase boundaries based on phase assemblages in recovered samples due to the limited data point at these regions. The dashed red line is proposed areotherm [17,25]. Gt, garnet; Cpx, clinopyroxene; Wd, wadsleyite; $\mathrm{Rw}$, ringwoodite; St, stishovite; $\mathrm{PhE}$, phase $\mathrm{E} ; \mathrm{PhD}$, phase $\mathrm{D} ; \mathrm{h}-\mathrm{Fe}$, iron-rich hydrous phase.

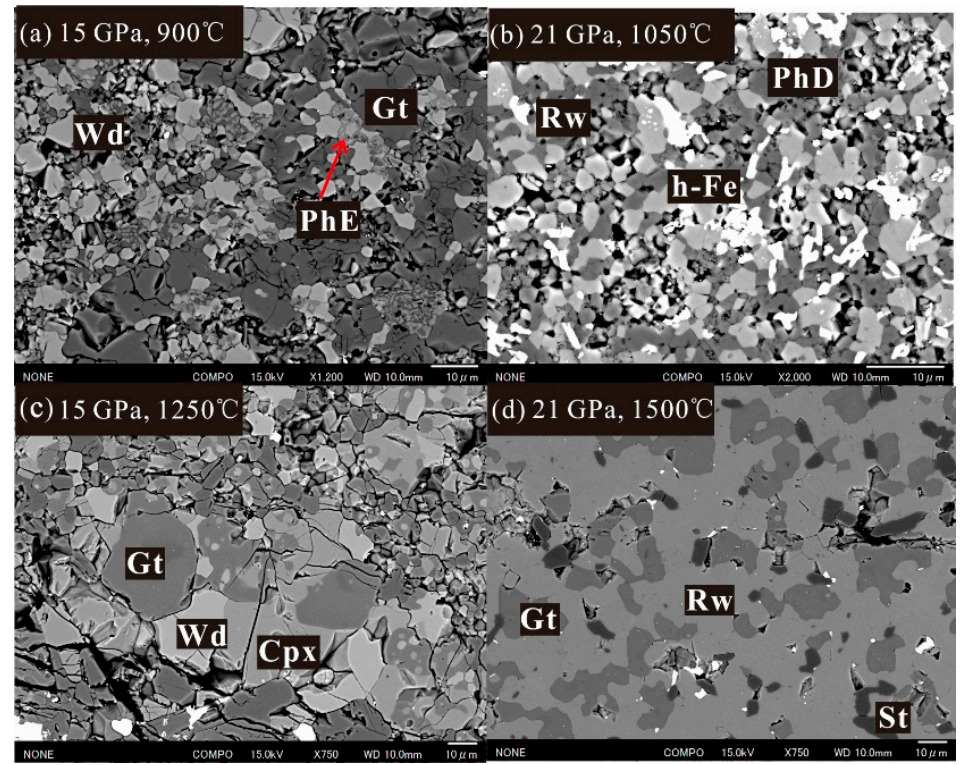

Figure 2. Backscattered electron images of representative run products under various pressure and temperature conditions: (a) $15 \mathrm{GPa}$ and $900{ }^{\circ} \mathrm{C}$; (b) $21 \mathrm{GPa}$ and $1050{ }^{\circ} \mathrm{C}$; (c) $15 \mathrm{GPa}$ and $1250{ }^{\circ} \mathrm{C}$; (d) $21 \mathrm{GPa}$ and $1500{ }^{\circ} \mathrm{C}$. Gt, garnet; $\mathrm{Cpx}$, clinopyroxene; $\mathrm{Wd}$, wadsleyite; Rw, ringwoodite; St, stishovite; $\mathrm{PhE}$, phase E; PhD, phase D; h-Fe, iron-rich hydrous phase.

Cpx was observed at $16.5 \mathrm{GPa}$ and $1300^{\circ} \mathrm{C}$, which further transformed to Gt at higher pressures. Stishovite (St) was found to be coexisting with $\mathrm{Rw}$ at temperatures higher than $1100{ }^{\circ} \mathrm{C}$. Some amount of ferrous oxide was detected at $21 \mathrm{GPa}$ and $1050{ }^{\circ} \mathrm{C}$. At $21 \mathrm{GPa}$ and $1000{ }^{\circ} \mathrm{C}$, we found iron-rich hydrous phase, based on analyzing the deficit of weight total. Both, the total weight and diffraction pattern, were similar to $\varepsilon \mathrm{FeOOH}$; however, the diffraction peaks were slightly shifted compared with $\varepsilon \mathrm{FeOOH}$, probably because of the incorporation of $\mathrm{Mg}$ due to the similar ionic radius of ${ }^{\mathrm{VI}} \mathrm{Mg}^{2+}(0.72 \AA)$ 
and ${ }^{\mathrm{VI}} \mathrm{Fe}^{2+}(0.78 \AA)$. It was also a little strange that this phase did not contain $\mathrm{Si}$ and Al. Perhaps, the solubility of $\mathrm{Al}$ and $\mathrm{Si}$ decreases when $\mathrm{Mg}$ is included. More work is needed to clarify this issue.

\subsection{Mineral Chemistry in DHMSs, Wadsleyite, and Ringwoodite}

The measured chemical compositions of the phases in the experiments are presented in Table 3. Several phases exhibited broad compositional variations. PhE had a composition of 4.5-3.1 wt.\% for $\mathrm{Al}_{2} \mathrm{O}_{3}$ and 12.8-8.5 wt.\% for $\mathrm{FeO}$, at elevated pressures and temperatures from $15 \mathrm{GPa}$ and $900{ }^{\circ} \mathrm{C}$ to $16.5 \mathrm{GPa}$ and $1100^{\circ} \mathrm{C}$. With increasing pressure from $18 \mathrm{GPa}$ to $21 \mathrm{GPa}$, the $\mathrm{Al}_{2} \mathrm{O}_{3}$ content decreased from 7.9 to $4.7 \mathrm{wt} . \%$. However, $\mathrm{FeO}$ remained almost stable at around $4.3 \mathrm{wt} . \%$. The water contents in $\mathrm{PhE}$ and $\mathrm{PhD}$ were both estimated for $13 \mathrm{wt} . \%$ on average, based on the deficit from the EDS weight total (each phase was calculated by summing all the deficit of weight total in Table 3 , and then divided by counted number). $\mathrm{PhD}$ in the MAFSH system generally had low amounts of $\mathrm{FeO}<4.4$ wt.\%. The $\mathrm{Al}_{2} \mathrm{O}_{3}$ contents were $3.5-7.9 \mathrm{wt} . \%$, whereas the $\mathrm{FeO}$ contents exhibited a small variation of 3.9-4.8 wt.\% throughout the samples quenched under various pressure and temperature conditions (Table 3).

Table 3. Representative mineral compositions.

\begin{tabular}{|c|c|c|c|c|c|c|c|}
\hline$P(\mathrm{GPa})$ & $T\left({ }^{\circ} \mathrm{C}\right)$ & Phase & $\mathrm{MgO}$ & $\mathrm{Al}_{2} \mathrm{O}_{3}$ & $\mathrm{SiO}_{2}$ & $\mathrm{FeO}$ & Total \\
\hline \multirow{12}{*}{21} & \multirow{3}{*}{1500} & Gt & $26.48(54)$ & $13.27(142)$ & $48.63(84)$ & $12.33(39)$ & $100.71(23)$ \\
\hline & & Rw & $36.20(29)$ & 0 & $38.11(32)$ & $25.42(45)$ & $99.73(66)$ \\
\hline & & St & 0 & $1.45(46)$ & $100.68(81)$ & 0.77 (6) & $102.90(52)$ \\
\hline & \multirow{3}{*}{1250} & $\mathrm{Gt}$ & $25.01(60)$ & $15.21(142)$ & $46.27(85)$ & $12.34(37)$ & $98.84(33)$ \\
\hline & & $\mathrm{Rw}$ & $35.72(33)$ & 0 & $37.49(23)$ & $24.95(43)$ & $98.15(58)$ \\
\hline & & St & 38.20 & $0.55(38)$ & $99(63)$ & $0.78(33)$ & 100.33 \\
\hline & \multirow{3}{*}{1050} & Rw & $41.60(98)$ & 0 & $39.27(62)$ & 15.99 (27) & $96.86(88)$ \\
\hline & & $\mathrm{PhD}$ & $20.24(42)$ & $4.71(71)$ & $56.11(85)$ & $4.79(34)$ & $85.86(145)$ \\
\hline & & h-Fe & $7.25(33)$ & 0 & $0.87(60)$ & $81.74(106)$ & 89.87 (120) \\
\hline & \multirow{3}{*}{900} & $\mathrm{Rw}$ & $43.57(86)$ & $1.33(7)$ & $40.54(73)$ & $12.11(87)$ & $96.22(143)$ \\
\hline & & $\mathrm{PhD}$ & $29.36(78)$ & $3.50(48)$ & $52.95(90)$ & $3.93(48)$ & $89.74(81)$ \\
\hline & & St & $1.53(71)$ & 0 & 99.08 (78) & $1.15(27)$ & $101.72(58)$ \\
\hline \multirow{3}{*}{19.5} & \multirow{3}{*}{1400} & Gt & $26.02(39)$ & $12.76(65)$ & $47.78(60)$ & $12.21(39)$ & $98.78(92)$ \\
\hline & & Rw & $35.26(13)$ & 0 & 36.96 (19) & $25.55(34)$ & $97.77(44)$ \\
\hline & & St & 0 & $0.96(47)$ & $98.42(58)$ & $0.72(32)$ & $100.10(81)$ \\
\hline \multirow{4}{*}{18} & \multirow{4}{*}{1550} & Gt & $27.78(29)$ & $11.04(37)$ & $49.70(30)$ & $12.45(80)$ & $100.45(37)$ \\
\hline & & $\mathrm{Rw}$ & $34.88(37)$ & $2.05(18)$ & $37.77(30)$ & $26.70(24)$ & $99.35(58)$ \\
\hline & & St & 0 & $1.54(58)$ & 99.90 (97) & $0.62(36)$ & $102.05(63)$ \\
\hline & & Melt & 20.65 & 1.62 & 16.45 & 16.57 & 55.31 \\
\hline \multirow{3}{*}{18} & \multirow{3}{*}{1200} & $\mathrm{Gt}$ & $25.88(90)$ & $12.61(99)$ & $47.96(67)$ & $12.41(64)$ & $98.86(76)$ \\
\hline & & Rw & 35.55 (35) & 0 & $37.56(34)$ & $25.61(47)$ & $98.71(79)$ \\
\hline & & St & 0 & $0.58(23)$ & 99.49 (71) & $0.70(40)$ & $100.77(82)$ \\
\hline \multirow{2}{*}{18} & \multirow{2}{*}{1000} & $\mathrm{Rw}$ & $32.89(61)$ & 0 & $36.98(46)$ & $27.86(81)$ & $97.73(57)$ \\
\hline & & $\mathrm{PhD}$ & $20.48(75)$ & $7.86(59)$ & 54.68 (73) & $4.57(46)$ & 87.59 (53) \\
\hline \multirow{3}{*}{16.5} & \multirow{3}{*}{1300} & $\mathrm{Gt}$ & $25.42(32)$ & $11.23(48)$ & 47.18 (29) & $12.76(57)$ & $96.59(50)$ \\
\hline & & Rw & $28.89(32)$ & 0 & $34.88(27)$ & $32.21(25)$ & $95.98(64)$ \\
\hline & & Cpx & $33.79(24)$ & $19.19(60)$ & $55.66(53)$ & $6.98(47)$ & $96.44(95)$ \\
\hline \multirow{4}{*}{16.5} & \multirow{4}{*}{1100} & Gt & $25.76(80)$ & $12.81(36)$ & $47.64(77)$ & $14.74(57)$ & $100.94(63)$ \\
\hline & & Rw & 34.59 (57) & 0 & $37.72(17)$ & $26.67(63)$ & $98.97(37)$ \\
\hline & & PhE & $38.42(75)$ & $3.12(20)$ & $37.82(18)$ & $8.47(28)$ & $87.82(57)$ \\
\hline & & St & $1.38(67)$ & $0.76(64)$ & 96.75 (75) & $1.14(20)$ & $100.03(27)$ \\
\hline
\end{tabular}


Table 3. Cont.

\begin{tabular}{|c|c|c|c|c|c|c|c|}
\hline$P(\mathrm{GPa})$ & $T\left({ }^{\circ} \mathrm{C}\right)$ & Phase & $\mathrm{MgO}$ & $\mathrm{Al}_{2} \mathrm{O}_{3}$ & $\mathrm{SiO}_{2}$ & $\mathrm{FeO}$ & Total \\
\hline \multirow{4}{*}{16} & \multirow{4}{*}{1200} & Gt & $24.28(47)$ & $13.42(37)$ & $46.67(33)$ & $14.26(83)$ & $98.63(44)$ \\
\hline & & $\mathrm{Rw}$ & $28.36(42)$ & 0 & 35.76 (39) & 33.43 (59) & 97.55 (69) \\
\hline & & $\mathrm{Wd}^{*}$ & - & - & - & - & - \\
\hline & & Cpx & 34.99 (51) & $20.70(54)$ & $56.73(58)$ & $6.52(37)$ & 98.25 (37) \\
\hline \multirow{3}{*}{15} & \multirow{3}{*}{1450} & $\mathrm{Gt}$ & $26.61(71)$ & $11.35(25)$ & $49.48(61)$ & $13.10(75)$ & $100.54(82)$ \\
\hline & & $\mathrm{Wd}$ & $34.43(35)$ & 0 & 37.35 (33) & $27.61(46)$ & $99.40(81)$ \\
\hline & & Cpx & $34.68(74)$ & 0 & $58.09(41)$ & $7.56(70)$ & $100.34(82)$ \\
\hline \multirow{3}{*}{15} & \multirow{3}{*}{1250} & Gt & 27.39 (13) & $11(54)$ & 49.79 (37) & $13.06(34)$ & $101.24(40)$ \\
\hline & & $\mathrm{Wd}$ & $30.91(34)$ & 0 & $36.54(18)$ & $32.11(47)$ & $99.55(46)$ \\
\hline & & Cpx & 35.80 (39) & 0 & $58.17(57)$ & $6.65(35)$ & $100.61(67)$ \\
\hline \multirow{3}{*}{15} & \multirow{3}{*}{1100} & $\mathrm{Gt}$ & $25.19(57)$ & $12.32(28)$ & $47.52(64)$ & $13.08(61)$ & $98.11(81)$ \\
\hline & & $\mathrm{Wd}$ & $31.03(96)$ & 0 & $36.49(80)$ & $30.23(94)$ & $97.76(46)$ \\
\hline & & Cpx & $35.32(70)$ & $30.91(34)$ & $56.57(72)$ & $6.27(81)$ & 98.16 (13) \\
\hline \multirow{3}{*}{15} & \multirow{3}{*}{900} & Gt & $27.61(31)$ & 12.45 (79) & 44.08 (83) & $17.22(96)$ & $101.35(74)$ \\
\hline & & $\mathrm{Wd}$ & $27.91(46)$ & 0 & $36.15(50)$ & 35.08 (27) & $99.14(84)$ \\
\hline & & $\mathrm{PhE}$ & $34.01(84)$ & $4.54(26)$ & $35.92(47)$ & $12.79(54)$ & $87.27(79)$ \\
\hline
\end{tabular}

* Measuring the chemical composition by EDS was difficult because of the small crystal size. This phase was identified by Raman spectrum. Gt, garnet; Cpx, clinopyroxene; Wd, wadsleyite; Rw, ringwoodite; St, stishovite; $\mathrm{PhE}$, phase $\mathrm{E} ; \mathrm{PhD}$, phase $\mathrm{D} ; \mathrm{h}-\mathrm{Fe}$, iron-rich hydrous phase.

The chemical composition changes in Rw and Gt that occur with increasing temperature at some different pressures are shown in Figure 3. The $\mathrm{MgO}$ and $\mathrm{SiO}_{2}$ contents decreased concomitantly with increasing temperature and then increased slightly in Rw at 16 and $21 \mathrm{GPa}$ (Figure 3a). However, the opposite trend was observed for $\mathrm{FeO}$ content. At $18 \mathrm{GPa}$, opposite trends were observed in $\mathrm{MgO}$, $\mathrm{SiO}_{2}$, and $\mathrm{FeO}$ contents below $1250{ }^{\circ} \mathrm{C}$ compared to pressures at 16 and $21 \mathrm{GPa}$. Both $\mathrm{Wd}$ and $\mathrm{Rw}$ have near-stoichiometric bulk composition. However, the ( $\mathrm{Mg}+\mathrm{Fe}) / \mathrm{Si}$ ratio of $\mathrm{Wd}$ and $\mathrm{Rw}$ was lower than 2, indicating incorporation of $\mathrm{H}^{+}$. The $\mathrm{H}_{2} \mathrm{O}$ contents in $\mathrm{Rw}$ were greater than those in $\mathrm{Wd}$, based on deficit total weight estimation. Generally, the $\mathrm{Al}_{3} \mathrm{O}_{2}$ and $\mathrm{SiO}_{2}$ contents in Gt exhibited an opposite tendency because of Tschermak substitution $\left(\mathrm{Mg}^{2+}+\mathrm{Si}^{4+}=2 \mathrm{Al}^{3+}\right)$. The $\mathrm{Al}_{3} \mathrm{O}_{2}$ content decreased, and the $\mathrm{SiO}_{2}$ content increased concomitantly with increasing temperature. However, with increasing pressure, the $\mathrm{Al}_{3} \mathrm{O}_{2}$ content increased, and the $\mathrm{SiO}_{2}$ content decreased (Figure $3 \mathrm{~b}$ ). The FeO content remained fundamentally unchanged in all quenched samples, except under the condition of $15 \mathrm{GPa}$ and $900{ }^{\circ} \mathrm{C}$ (Table 3).

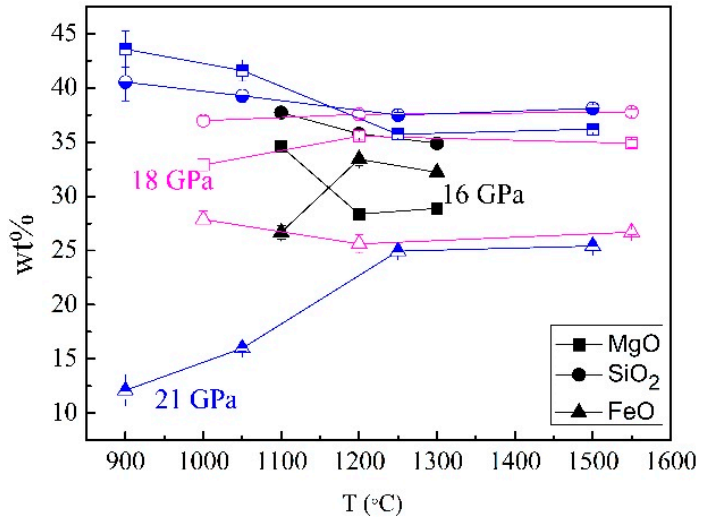

(a)

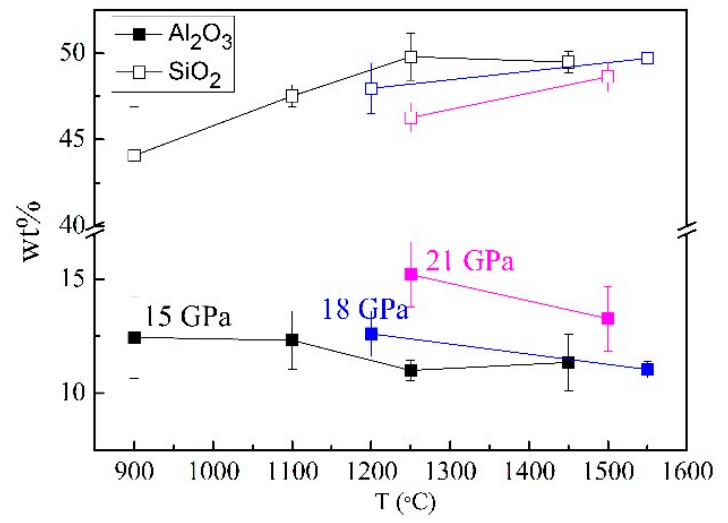

(b)

Figure 3. Chemical composition changes in ringwoodite (a) and garnet (b) with increasing temperature at different pressures. 


\subsection{Stability and Water Contents of Hydrous Phases in Iron-Rich Martian Mantle}

Several reports of petrological studies have described that dense hydrous magnesium silicates (DHMSs) remain stable in the hydrous pyrolite mantle compositions along a cold subducting slab [1,3,21]. In the present study, we observed that the stability regions of DHMSs in the hydrous iron-rich Martian mantle $\left(2 \mathrm{wt} . \% \mathrm{H}_{2} \mathrm{O}\right.$ ) were generally consistent with those obtained in $\mathrm{CaO}-\mathrm{MgO}-\mathrm{Al}_{2} \mathrm{O}_{3}-\mathrm{SiO}_{2}$ (CMAS) pyrolite with 2 wt.\% of $\mathrm{H}_{2} \mathrm{O}$ and a water-saturated $\mathrm{MSH}$ system. However, some differences were apparent.

The stability region of PhE partially overlapped with Wd or Rw below $17 \mathrm{GPa}$ in the low-temperature field. Although Wd could hold up to $3 \mathrm{wt}$ \% of $\mathrm{H}_{2} \mathrm{O}$ in its crystal structure [24], it only accommodated approx. 0.8 wt. $\%$ of $\mathrm{H}_{2} \mathrm{O}$ in a water-undersaturated condition at $15 \mathrm{GPa}$ and $900{ }^{\circ} \mathrm{C}$. The water content increased drastically to approx. $2.2 \mathrm{wt} . \%$ after $\mathrm{PhE}$ decomposed at elevated temperature $1100^{\circ} \mathrm{C}$ and $15 \mathrm{GPa}$. It subsequently decreased to approx. $0.6 \mathrm{wt} . \%$ with the temperature increased to $1450{ }^{\circ} \mathrm{C}$. The water content in $\mathrm{Wd}$ was consistent with those proposed in CMAS pyrolite with 2 wt. $\%$ of $\mathrm{H}_{2} \mathrm{O}$ at $15 \mathrm{GPa}$ and $1450{ }^{\circ} \mathrm{C}$ [24], indicating that Wd also has large water storage capacity within the stability field of the Martian mantle.

Reportedly, SuB appears in CMAS or MHS systems at pressures higher than 17 GPa [24], but we observed PhD instead of SuB at 18-21 GPa, which means that much water might be held in the low-temperature region because of the higher water solubility in $\mathrm{PhD}$. It is expected that PhD might transport water to the deepest part of the Martian interior because PhD was reported to be stable up to $44 \mathrm{GPa}$, which corresponds to a depth of $1250 \mathrm{~km} \mathrm{[6].}$

Hydrous Rw appeared at pressures higher than $16.5 \mathrm{GPa}$, which exhibited a wider stability region than that in hydrous pyrolite. It seemed readily apparent that water contents in Rw decreased concomitantly with increasing temperature, as shown in Table 2 . We observed trace amounts of melt at $18 \mathrm{GPa}$ and $1550{ }^{\circ} \mathrm{C}$, suggesting that it was very close to the wet solidus in MAFS system under a water-unsaturated condition. We also observed some amount of iron-rich hydrous phase at $21 \mathrm{GPa}$ and $1050{ }^{\circ} \mathrm{C}$, implicating it is a potential water carrier in low-temperature regions of the hydrous iron-rich Martian mantle. Because of its greater density than its surrounding materials, it might bring water to the Martian core.

\section{Implications}

The existence of water on Mars has long been controversial. Some evidence has shown that water disappeared from the Mars surface after its formation [17,26,27]. Although the whereabouts of the water have long been debated, some parts of the hydrated crust of Mars may have been brought into the deep interior by the convecting mantle. We inferred that DHMSs might act as an important water carrier in the deep region of Fe-rich Mars, although the temperature profile of the Mars interior remains unclear. Several models have been proposed to constrain the structure of the Martian interior based on geophysical observations and high-pressure petrological studies. Then, they suggested the pressure of the core-mantle boundary as 19-25 GPa [25,28,29]. Our results demonstrated that DHMSs could be expected to transport water even to the iron-rich Martian core in the cold region in this pressure range.

PhE and PhD were potentially relevant DHMSs in the Martian transition zone in a simplified MAFSH model. The DHMSs would dehydrate completely if the temperature of the surrounding Martian mantle was higher than their stability limits (Figure 2). The released water would be stored in Wd or Rw. These phases might subsequently act as a large water reservoir in the Martian mantle, as in the Earth's mantle. The results of the present phase relation in iron-rich Martian mantle were fundamentally consistent with data for hydrous pyrolite, except for the SuB absence in the present study. In addition, it is noteworthy that much more water could be held in the Martian mantle than in Earth's mantle because the phase transition pressure of the loop in both olivine (Ol)-Wd and Wd-Rw boundary shifted towards lower pressure [22,24].

Furthermore, it seems that the thermal structure of Mars is key to understand water cycles in a deeper region; however, the areotherm of Mar's is still under debate $[17,25,28]$. In this study, 
we adopted a model areotherm, as shown in Figure 1, which was determined according to the present day core-mantle boundary temperature of $\sim 1400{ }^{\circ} \mathrm{C}$ suggested by Hauck and Phillips [17]. In this model, Mars was slowly cooling down from $4.5 \mathrm{Ga}$ to the present whose areotherm was still at least higher than the dehydration temperature of $\mathrm{PhE}$ and $\mathrm{PhD}$, as shown in Figure 1. During the evolution of early Mars, much of the water was possibly lost because of low melting temperatures of DHMSs, hydrous Wd, and Rw compared with areotherm [17]. In addition, water is an incompatible and volatile component in a solid-melt system, which easily causes partial melting of Martian mantle. Water also affects the thermal evolution of the planet. The generated magma may bring the released water to the shallow region, and help conduct and transfer heat more efficiently. This process may help early Martian mantle quickly cool down than a dry system. By contrast, this may become a barrier for water transportation at least to some critical depth during some part of Martian history. However, the accumulated water in the shallow region may hydrate some part of the crust. Unlike the Earth system in which water is recycled by subducting slabs, the mantle of Mars might be convected, but the crust is stagnant and not subducted [17]. The mantle might be hydrated by reaction with the overlying hydrous crust. Eventually, the water should be restored in Wd and Rw during mantle convection due to their high thermal stability region than that of DHMSs.

Our present result indicated that both DHMSs and nominally anhydrous minerals, Wd and Rw, have the potential to accommodate a certain amount of water, elucidating model geodynamic processes associated with the deepwater cycles of Mars.

Author Contributions: Conceptualization, C.X.; data curation, C.X.; writing (original draft preparation), C.X.; writing (review and editing), T.I.; supervision, T.I.; funding acquisition, C.X. and T.I.

Funding: This research was funded by JSPS KAKENHI Grant Numbers 18J12511 for C.X. and 26247073, 15H05828, and $18 \mathrm{H} 03740$ for T.I. In addition, C.X. was supported by Research Fellowships of the Japan Society for the Promotion of Science (JSPS) for Young Scientists (DC2).

Acknowledgments: The authors are grateful to Takeshi Arimoto for the preparation of starting materials.

Conflicts of Interest: The authors declare no conflict of interest.

\section{References}

1. Gasparik, T. The role of volatile in the transition zone. J. Geophys. Res. 1993, 98, 4287-4299. [CrossRef]

2. Ohtani, E.; Touma, M.; Litasov, K.; Kubo, T.; Suzuki, A. Stability of hydrous phases and water storage capacity in the transitional zone and lower mantle. Phys. Earth Planet. Inter. 2001, 124, 105-117. [CrossRef]

3. Komabayashi, T.; Omori, S. Internally consistent thermodynamic dataset for dense hydrous magnesium silicates up to $35 \mathrm{GPa}, 1600^{\circ} \mathrm{C}$ : Implications for water circulation in the Earth's deep mantle. Phys. Earth Planet. Int. 2006, 156, 89-107. [CrossRef]

4. Litasov, K.; Ohtani, E.; Sano, A.; Suzuki, A.; Funakoshi, K. Wet subduction versus cold subduction. Geophys. Res. Lett. 2005, 32, 1-5. [CrossRef]

5. Ghosh, S.; Schmidt, M. Melting of phase D in the lower mantle and implications for recycling and storage of $\mathrm{H}_{2} \mathrm{O}$ in the deep mantle. Geochim. Cosmochim. Acta 2014, 145, 72-88. [CrossRef]

6. Nishi, M.; Irifune, T.; Tsuchiya, J.; Tange, Y.; Nishihara, Y.; Fujino, K.; Higo, Y. Stability of hydrous silicate at high pressures and water transport to the deep lower mantle. Nat. Geosci. 2014, 7, 224-227. [CrossRef]

7. Pamato, M.; Myhill, R.; Ballaran, T.; Frost, D.; Heidelbach, F.; Miyajima, N. Lower-mantle water reservoir implied by the extreme stability of a hydrous aluminosilicate. Nat. Geosci. 2015, 8, 75-79. [CrossRef]

8. Walter, M.J.; Thomson, A.R.; Wang, W.; Lord, O.T.; Ross, J.; McMahon, S.C.; Baron, M.A.; Melekhova, E.; Kleppe, A.K.; Kohn, S.C. The stability of hydrous silicates in Earth's lower mantle: Experimental constraints from the systems $\mathrm{MgO}-\mathrm{SiO}_{2}-\mathrm{H}_{2} \mathrm{O}$ and $\mathrm{MgO}-\mathrm{Al}_{2} \mathrm{O}_{3}-\mathrm{SiO}_{2}-\mathrm{H}_{2} \mathrm{O}$. Chem. Geol. 2015, 418, 16-29. [CrossRef]

9. Liu, X.; Matsukage, K.; Nishihara, Y.; Suzuki, T.; Takahashi, E. Stability of the hydrous phases of Al-rich phase $\mathrm{D}$ and Al-rich phase $\mathrm{H}$ in deep subducted oceanic crust. Am. Mineral. 2019, 104, 64-72. [CrossRef]

10. Inoue, $\mathrm{T}$. Effect of water on melting phase relations and melt composition in the system $\mathrm{Mg}_{2} \mathrm{SiO}_{4}-\mathrm{MgSiO}_{3}-\mathrm{H}_{2} \mathrm{O}$ up to 15 GPa. Phys. Earth Planet. Inter. 1994, 85, 237-263. [CrossRef] 
11. Cardenas, B.; Mohrig, D.; Goudge, T. Fluvial stratigraphy of valley fills at Aeolis Dorsa, Mars: Evidence for base-level fluctuations controlled by a downstream water body. GSA Bull. 2018, 130, 484-498. [CrossRef]

12. Chan, N.; Perron, J.; Mitrovica, J.; Gomez, N. New Evidence of an Ancient Martian Ocean from the Global Distribution of Valley Networks. J. Geophys. Res. 2018, 123, 2138-2150. [CrossRef]

13. Ivanov, M.; Erkeling, G.; Hiesinger, H.; Bernhardt, H.; Reiss, D. Topography of the deuteronilus contact on mars: Evidence for an ancient water/mud ocean and long-wavelength topographic readjustments. Planet. Space Sci. 2017, 144, 49-70. [CrossRef]

14. Byrne, S.; Dundas, C.; Kennedy, M. Distribution of mid-latitude ground ice on Mars from new impact craters. Science 2009, 325, 1674-1676. [CrossRef] [PubMed]

15. Conway, S.J.; Balme, M.R.; Kreslavsky, M.A.; Murray, J.B.; Towner, M.C. The comparison of topographic long profiles of gullies on Earth to gullies on Mars: A signal of water on Mars. Icarus 2016, 253, 189-204. [CrossRef]

16. Pan, L.; Ehlmann, B. Aqueous Processes from Diverse Hydrous Minerals in the Vicinity of Amazonian-Aged Lyot Crater. J. Geophys. Res. 2018, 123, 1618-1648. [CrossRef]

17. Hauck, S.A.; Phillips, R.J. Thermal and crustal evolution of Mars. J. Geophys. Res. Planets 2002, 107. [CrossRef]

18. Frost, D.J.; Fei, Y.W. Stability of phase D at high pressure and high temperature. J. Geophys. Res. 1998, 103, 7463-7474. [CrossRef]

19. Ohira, I.; Ohtani, E.; Sakai, T.; Miyahara, M.; Hirao, N.; Ohishi, Y.; Nishijima, M. Stability of a hydrous $\delta$-phase, $\mathrm{AlOOH}-\mathrm{MgSiO}_{2}(\mathrm{OH})_{2}$, and a mechanism for water transport into the base of lower mantle. Earth Planet. Sci. Lett. 2014, 401, 12-17. [CrossRef]

20. Dreibus, G.; Wänke, H. Mars, a volatile-rich planet. Icarus 1987, 71, 225-240. [CrossRef]

21. Ohtani, E.; Litasov, K.; Hosoya, T.; Kubo, T.; Kondo, T. Water transport into the deep mantle and formation of a hydrous transition zone. Phys. Earth Planet. Inter. 2004, 143-144, 255-269. [CrossRef]

22. Litasov, K.D.; Ohtani, E.; Sano, A. Influence of water on major phase transitions in the Earth's mantle. In Earth Deep Water Cycle; Jacobsen, S.D., van der Lee, S., Eds.; Geophysical Monograph Series; Wiley Blackwell: Hoboken, NJ, USA, 2006; Volume 168, pp. 95-111.

23. Akaogi, M.; Ito, E.; Navrotsky, A. Olivine-modified spinel-spinel transitions in the system $\mathrm{Mg}_{2} \mathrm{SiO}_{4}-\mathrm{Fe}_{2} \mathrm{SiO}_{4}$ : Calorimetric measurements, thermochemical calculation, and geophysical application. J. Geophys. Res. 1989, 94, 15671-15685. [CrossRef]

24. Litasov, K.; Ohtani, E. Stability of various hydrous phases in CMAS pyrolite- $\mathrm{H}_{2} \mathrm{O}$ system up to $25 \mathrm{GPa}$. Phys. Chem. Miner. 2003, 30, 147-156. [CrossRef]

25. Bertka, C.M.; Fei, Y.W. Mineralogy of Martian interior up to core-mantle boundary pressures. J. Geophys. Res. 1997, 102, 5251-5264. [CrossRef]

26. Baker, V.R. Water and the Martian landscape. Nature 2001, 412, 228-236. [CrossRef] [PubMed]

27. Masson, P.; Carr, M.H.; Costard, F.; Greeley, R.; Hauber, E.; Jaumann, R. Geomorphologic evidence for liquid water. Space Sci. Rev. 2001, 96, 333-364. [CrossRef]

28. Zharkov, V.N.; Gudkova, T.V. Seismic model of Mars: Effects of hydration. Planet. Space Sci. 2014, 104, 270-278. [CrossRef]

29. Raevskiy, S.N.; Gudkova, T.V.; Zharkov, V.N. Diagnostic possibilities of body waves for studying the interior structure of Mars. Izv-Phys. Solid Eart. 2015, 51, 143-155. [CrossRef]

(C) 2019 by the authors. Licensee MDPI, Basel, Switzerland. This article is an open access article distributed under the terms and conditions of the Creative Commons Attribution (CC BY) license (http://creativecommons.org/licenses/by/4.0/). 